ISSN No. 0974-035X

An Indexed, Refereed \& Peer Reviewed Journal of Higher Education

\title{
A STUDY OF ENVIRONMENTAL AWARENESS OF HIGH SCHOOL STUDENTS OF AHMEDABAD IN RELATION TO CERTAIN VARIABLES
}

\section{Dr. Dhaval R.Patel}

\section{- INTRODUCTION}

It is observed that environment constitutes a very important part of our life. To understand life without studying the impact of environment is simply impossible. All human activities have an impact on environment. In the past two decades, environment has attracted the attention of decision makers, scientists and even layman in many parts of the world. They are becoming increasingly conscious of issues such as famines, droughts, floods, scarcity of fuel, firewood and fodder, pollution of air and water, problems of hazardous chemicals and radiation, depletion of natural resources, extinction of wildlife and dangers to flora and fauna.

People are now aware of the need to protect the natural environment resources of air, water, soil and plant life that constitute the natural capital on which man depends. Unless environmental issues are not solved or not taken care of the coming generations may find earth, worth not living. There is no denying the fact that environment has to be protected and conserved so as to make future life possible. On 22 ${ }^{\text {nd }}$ April, 2004, the Supreme Court approved the model syllabus for environmental education prepared by NCERT; which the Court had directed to make a compulsory subject up to pre-service curriculum. Before designing and implementing any teacher trainee's curriculum on environmental education, it is essential for the teacher to gather baseline data about the awareness of the environment. 


\section{- OBJECTIVES OF THE STUDY}

\section{The objectives of the study are as follows:}

1 To study the Environmental Awareness of High School Students with respect to Gender.

2 To study the Environmental Awareness of High School Students with respect to Type of School.

3 To study the Environmental Awareness of High School Students with respect to their achievement in Environmental Science.

\section{- HYPOTHESES OF THE STUDY}

The most important step of a scientific investigation is to formulate hypothesis. The hypothesis is a tentative solution of a problem.

\section{Following Null hypotheses are formulated for the present study:}

H01: There is no significant difference between the mean scores of Environmental Awareness of Male and Female High School Students of Ahmedabad.

Ho2: There is no significant difference between the mean scores of Environmental Awareness of Aided Schools and Unaided Schools of Ahmedab 5

H03: There is no significant relationship between the Environmental Awareness and achievement in Environmental Science subject of students of IX ${ }^{\text {th }}$ grade.

\section{- RESEARCH DESIGN}

The most important step of any scientific research is to prepare a research design. It is a blueprint of whole research process devoid of ordered sequential step-by-step procedure. It is a plan that specifies the sources and types of information relevant to the research problem. 


\section{Population}

\section{According to the Best and Khan:}

"A population is defined as a group of individuals with at least one common characteristic which distinguishes that group from other individuals."

In the present study the population consists of students of Ahmedabad city studying inIX ${ }^{\text {th }}$ grade in academic year 2014-15.

\section{Sample}

\section{According to V. Young:}

"A sample is a short form of the well-defined clear group (population)".

In the present study the multistage sampling technique will be used at the first stage. Then random selection from schools will be done. Finally Cluster Sampling will be done as to select 330 students of IX ${ }^{\text {th }}$ grade as the sample subject from the given population.

\section{Method}

In the present study survey method has been used.

In survey research, sample drawn from the population are studied and inferences are made about the whole population. Therefore a great deal of information can be obtained from a large population with much less expense. The method was suitable for the study because this involved a large sample.

\section{Tool}

Tools are the most important part of research. Without tools, the research cannot be carried out. Tools help in collection of certain types of information. Tools help in providing data and seek for testing hypothesis. A researcher requires different tools to gather data for the research. 
Towards Excellence: An Indexed, Refereed \& Peer Reviewed Journal of Higher Education / Dr.

Dhaval Patel / Page 1-6

In the present Study, a 5 point rating scale regarding environmental awareness will be used prepared by researcher. This tool was standardized on the Secondary students of Ahmedabad as a sample subject. Therefore this test being most applicable and eventually latest, the same shall be applied to the said sample.

\section{- PLANNING OF DATA COLLECTION}

After selecting appropriate tool, methodology and the sample and seeking the permission from the school, the researcher shall go to school on the decided date and time and shall administer the test as required and as per the instruction; similarly the test shall be administered in the other schools on all the samples and thus the data.

\section{- DATA ANALYSIS}

After the data collection researcher shall conduct the scoring of the tools and shall score each of the tool as per the key, this data would be called as raw data. The raw data being not sufficient to provide the information as required. The raw data shall be grouped as per the requirement and then the statistical techniques as mean, standard deviation, co-relation and t-test shall be used for the analysis and hence the interpretation, since the data obtained will be on the internal scale normally distributed and the variance being homogeneous from 330 students shall be collected.

\section{- $\quad$ FINDINGS}

\section{The researcher arrived at the following findings through the data analyzed and interpreted:}

1) There exists no significant difference between mean scores of Environmental Awareness of Male and Female IX ${ }^{\text {th }}$ grade students. Moreover the mean scores of Environmental Awareness of Male and Female donot differ significantly. Thus it is clear that Male and Female of IX $^{\text {th }}$ grade students possess no difference in Environmental Awareness.

2) There exists significant difference between mean scores of Environmental Awareness of Aided and Unaided Schools of Ahmedabad. Moreover the mean scores of Environmental Awareness of IX $^{\text {th }}$ grade students of Aided and Unaided schools differ significantly. Thus it is clear that 
Towards Excellence: An Indexed, Refereed \& Peer Reviewed Journal of Higher Education / Dr.

Dhaval Patel / Page 1-6

IX $^{\text {th }}$ grade students of Aided and Unaided Schools possess difference in Environmental Awareness.

3) There exists significant correlation between mean scores of Environmental Awareness and Environmental Science Scores of IX ${ }^{\text {th }}$ grade students of Ahmedabad. Moreover the mean scores of Environmental Awareness of the IX ${ }^{\text {th }}$ grade students is high if their environmental science scores are also high. Thus it is clear that $\mathrm{IX}^{\text {th }}$ grade students have high correlation between Environmental Science Scores and Environmental Awareness.

\section{$\underline{\text { References }}$}

- Aggrawal, J. C. (2011). 'Essentials of Examination System', Noida: Vikas Publishing House Pvt Ltd. p. 1.

- Aggrawal, J. C. (1983). "Educational Research- An Introduction" (3rd Ed), New Delhi: Arya Book Depot., p.103.

- Angus, Stevenson (2002). Concise Oxford dictionary, $10^{\text {th }}$ edition.

- Barr, Davis and Johnson, (2007). Research in Education, New Delhi: Atlantic Publishers and Distributors (P) Ltd., p. 133.

- Basu, (1986). Environmental Protection-a many faced problem, New Delhi: Ministry of Information and broadcasting Yojana.

- Best, J.W. (1977). Research in Education, Prentice Hall Inc. cited by B. N. Pandey

- Broudly, (1963). Basic Edcuation, New York: Discovery Publishing

- Buch, M. B. (1997). Third Survey of Research in Education, New Delhi: NCERT

- Good C.V. (1945). Dictionary in Education, New York: Mac Graw Hill Company, p. 495. 
Towards Excellence: An Indexed, Refereed \& Peer Reviewed Journal of Higher Education / Dr. Dhaval Patel / Page 1-6

- Good C.V. (2008). Research Methodology: Techniques and Trends, New Delhi: APH Publishing Corporation, p.60.

- Deb, S.C. (2003). Environment Management, Mumbai: Jaico Publishing House.

- Garrett H.E. (1971) Statistics in Psychology and Education, Bombay: VakillsFerror and Simons Pvt. Ltd.

- Hakim, M.A. and Asthana B. Research Methods psychology, Agra: VinodPustakMandir, Third Edition.

\section{Dr.Dhaval R.Patel \\ Vision College of Education \\ Ahmedabad-09}

